\title{
Real-Time Fluorescent Polymerase Chain Reaction Detection of Phytophthora ramorum and Phytophthora pseudosyringae Using Mitochondrial Gene Regions
}

\author{
Paul W. Tooley, Frank N. Martin, Marie M. Carras, and Reid D. Frederick
}

First, third, and fourth authors: U.S. Department of Agriculture-Agricultural Research Service (USDA-ARS), Foreign Disease-Weed Science Research Unit, Ft. Detrick, MD 21702; and second author: USDA-ARS, 1636 East Alisal St., Salinas, CA 93905. Accepted for publication 24 November 2005.

\begin{abstract}
Tooley, P. W., Martin, F. N., Carras, M. M., and Frederick, R. D. 2006. Real-time fluorescent polymerase chain reaction detection of Phytophthora ramorum and Phytophthora pseudosyringae using mitochondrial gene regions. Phytopathology 96:336-345.

A real-time fluorescent polymerase chain reaction (PCR) detection method for the sudden oak death pathogen Phytophthora ramorum was developed based on mitochondrial DNA sequence with an ABI Prism 7700 (TaqMan) Sequence Detection System. Primers and probes were also developed for detecting $P$. pseudosyringae, a newly described species that causes symptoms similar to $P$. ramorum on certain hosts. The species-specific primer-probe systems were combined in a multiplex

than for many other described PCR procedures for detecting Phytophthora species. The assay was also used in a three-way multiplex format to simultaneously detect $P$. ramorum, $P$. pseudosyringae, and plant DNA in a single tube. $P$. ramorum was detected down to a $10^{-5}$ dilution of extracted tissue of artificially infected rhododendron 'Cunningham's White', and the amount of pathogen DNA present in the infected tissue was estimated using a standard curve. The multiplex assay was also used to detect $P$. ramorum in infected California field samples from several hosts determined to contain the pathogen by other methods. The real-time PCR assay we describe is highly sensitive and specific, and has several advantages over conventional PCR assays used for $P$. ramorum detection to confirm positive $P$. ramorum finds in nurseries and elsewhere.
\end{abstract} assay with a plant primer-probe system to allow plant DNA present in extracted samples to serve as a positive control in each reaction. The lower limit of detection of $P$. ramorum DNA was $1 \mathrm{fg}$ of genomic DNA, lower
Additional keywords: coxI, coxII.
Phytophthora ramorum (Werres, De Cock \& Man in’t Veld) sp. nov. causes sudden oak death, a serious disease of California oak species such as coast live oak (Quercus agrifolia) and tan oak (Lithocarpus densiflorus) (44). The pathogen also is widespread in Europe primarily as a pathogen of ornamentals $(14,28,40,59$, $60)$. Because of concern that $P$. ramorum may spread eastward and threaten the vast oak forests of the Eastern United States, state, federal, and Canadian regulations were drafted in 2001 that restricted movement of $P$. ramorum hosts out of infested areas of California $(7,8,42)$.

In 2003, new $P$. ramorum outbreaks were reported in nursery stock found in nurseries from Oregon, Washington, Canada, and additional areas of California $(22,41$; J. Jones, personal communication). Also in 2003, a national $P$. ramorum survey was initiated (12). In 2004, several large west coast production nurseries and some smaller nurseries were confirmed to be infested with $P$. ramorum. These facilities shipped over 2 million host plants, of which only a small portion were infected, to 49 states and the District of Columbia (51; J. Jones, personal communication). Efforts were made on the part of several agencies including the USDA Animal and Plant Health Inspection Service (APHIS), U.S. Forest Service, and State Departments of Agriculture to track and test the

Corresponding author: P. W. Tooley; E-mail address: paul.tooley@ars.usda.gov

* The $\boldsymbol{e}$-Xtra logo stands for "electronic extra" and indicates that the online version contains supplemental material not included in the print edition. The online version contains a link to F. Martin's website where additional data are presented.

DOI: 10.1094/PHYTO-96-0336

This article is in the public domain and not copyrightable. It may be freely reprinted with customary crediting of the source. The American Phytopathological Society, 2006. shipments, monitor for presence of $P$. ramorum in Eastern states, and educate the public about sudden oak death. By the end of 2004, 171 locations (wholesale nurseries and retail outlets) in 20 states were found to contain plants infected with $P$. ramorum. On 22 April 2004, APHIS issued an amended Emergency Order that implemented new restrictions on interstate movement of host nursery stock and associated articles from all commercial nurseries in California that are outside the quarantined area. Nurseries in Oregon and Washington that ship interstate were added to this regulatory oversight on 10 January 2005 . This order also listed 31 confirmed hosts of P. ramorum (those for which Koch's postulates had been performed) and a list of 37 additional plant species associated with $P$. ramorum because results of culture or polymerase chain reaction (PCR) tests had returned results positive for the pathogen. The host range of $P$. ramorum continues to increase as the pathogen is identified on an ever-widening group of plant species (13,24,31,41; J. Jones, personal communication).

In light of the recent movement of $P$. ramorum to the Eastern United States through shipment of nursery stock, the availability of rapid, sensitive and specific $P$. ramorum detection methods are needed. Unequivocal identification of $P$. ramorum is the goal of survey workers, as false identification and/or confusion of P. ramorum with other Phytophthora species could lead to the development of improper quarantine measures and/or rejection of plant shipments by state inspectors. P. ramorum has several distinguishing morphological characters that may be used for identification. It is characterized by semipapillate, deciduous sporangia with short pedicels and high length to width ratios, large chlamydospores, relatively slow growth, and low cardinal temperatures for growth (60). To accurately assess morphological features, however, requires experience in Phytophthora identification as 
some characteristics often show a continuum among different species. It can also be time consuming, especially when a number of samples have to be processed. Furthermore, it can be difficult to culture the pathogen from infected tissue at certain times of the year (23).

As an adjunct to morphological identification, several molecular procedures for identification and detection of $P$. ramorum have been developed and are in use in various laboratories and state and federal agencies. These include classical PCR methods based on internal transcribed spacer (ITS) regions of ribosomal DNA $(13,23,61)$ and mitochondrial gene regions (39), PCR-singlestrand conformation polymorphism analysis (32), and PCRrestriction fragment length polymorphism (RFLP) analysis (38). In 2004, a single nucleotide polymorphism procedure was also developed to allow differentiation among $P$. ramorum isolates from Europe and North America (33). In 2003, APHIS adopted the ITS-based conventional nested PCR method (13) as an accepted protocol for identification of $P$. ramorum and has stated in an amended order dated 22 April 2004 that positive (conventional) nested PCR tests alone may be used to confirm presence of $P$. ramorum and prohibit movement of affected nursery stock, without requiring confirmatory culturing of the pathogen (54).

Real-time PCR is based on the labeling of primers, probes, or amplicon with fluorogenic molecules and allows detection of the target fragment to be monitored while the amplification is in progress $(35,46)$. In $5^{\prime}$ fluorogenic real-time PCR (TaqMan), a sequence-specific oligonucleotide probe labeled with a fluorescent reporter and a quencher generates fluorescence at a rate directly proportional to the amount of product amplified in the reaction (26). The method is now being applied to a range of organisms in many different research applications $(30,34,35,43,50)$, including detection and quantification of fungal plant pathogens $(1,3,18,19$, $21,46,47,48,55,56)$. For Phytophthora species, real-time PCR has been used in studies detecting and quantifying levels of various species in host plants and soil $(4,29,47,56)$.

Several real-time PCR assays have been described for detection of $P$. ramorum. Bilodeau et al. (2) described an assay based on the ITS, $\beta$-tubulin, and elicitin regions using TaqMan and SYBR green assays. Hughes et al. (27) described an ITS-based real-time PCR assay for $P$. ramorum that uses TaqMan chemistry and has been adapted for field use with a SmartCycler (Cepheid, Inc., Sunnyvale, CA) instrument. A real-time PCR procedure for detection of $P$. ramorum based on the ITS region using SYBR green has been described by Hayden et al. (23).

Here, we describe the development of a real-time PCR assay for the sudden oak death pathogen $P$. ramorum based upon mitochondrial sequences. In previous work, we characterized the coxI and II genes in Phytophthora and described a conventional PCR assay for $P$. ramorum (36-39). In this study, we utilize the same primers as the conventional PCR method previously described (39), except with the addition of TaqMan probes specially designed for $P$. ramorum, $P$. pseudosyringae, and plant DNA. Plant primers were used as a positive control to insure that PCR amplification always occurs with DNA extracted from symptomatic samples. The real-time PCR assay we describe provides a sensitive, specific tool for detection of $P$. ramorum, based on a genomic region not used in other $P$. ramorum assays. It offers advantages over conventional PCR procedures as a stand-alone method or confirmatory procedure for workers monitoring for the presence of $P$. ramorum in new geographic regions.

\section{MATERIALS AND METHODS}

Cultures and DNA extraction. Phytophthora isolates (Table 1) were maintained on rye A agar (9) at $20^{\circ} \mathrm{C}$ in darkness and all were used to test primer and probe specificity. Genomic DNA was extracted according to Goodwin et al. (20) from $60 \mathrm{mg}$ of lyophilized mycelium grown on a synthetic medium (63). DNA concentrations were determined with a spectrophotometer (Model ND-1000; Nanodrop Technologies, Wilmington, DE) and by comparison with known DNA standards using agarose gel electrophoresis. Plant genomic DNA was extracted from noninoculated leaves with a Qiagen DNeasy Plant Maxi Kit (Qiagen Inc., Valencia, CA). Leaves of rhododendron 'Cunningham's White' were inoculated with sporangia of $P$. ramorum isolate 0 217 as described by Tooley et al. (53). California bay laurel (Umbellularia californica) was artificially inoculated with $P$. ramorum, $P$. pseudosyringae, or both pathogens by placing a 6-mm-diameter agar plug of mycelium on a wound on the leaf and incubating it in a moist chamber for 7 days. Total DNA was extracted by homogenizing two 6-mm-diameter leaf disks from lesions on infected leaves in a Fastprep FP120 instrument (Qbiogene, Inc., Carlsbad, CA) and using a Qbiogene FastDNA Kit according to the manufacturer's instructions.

Field samples from California. Samples of total DNA from symptomatic plants collected from the field were processed at the California Department of Food and Agriculture as described previously (39). The presence of Phytophthora spp. was confirmed by plating tissue on differential medium, and DNA was extracted from diseased tissue and tested with the ITS marker system (13) to determine if $P$. ramorum was present. Samples were also assayed with the mitochondrial marker system described in Martin et al. (39). Real-time PCR assays were conducted on 53 samples from 11 hosts in blind fashion; the samples were numbered randomly and the results of culturing and/or conventional PCR were not known until real-time PCR analyses were completed. DNA samples were also diluted 1:10 with sterile water prior to use because undiluted samples some times amplified poorly.

Primers, probes, and PCR conditions. The nucleotide sequences of the gene regions from which primer and probe sequences were designed are as described previously (39). Plant primers FMPl-2b and FMPl-3b (Table 2) were constructed from the mitochondrially encoded cytochrome oxidase I gene and generated a target fragment of $143 \mathrm{bp}$ (39). Species-specific primers for $P$. ramorum (FMPr-1a and FMPr-7) and $P$. pseudosyringae (FMPps-1c and FMPps-2c) amplified spacer sequences between the coxII and coxI genes and produced amplicons of 134 and 158 bp, respectively (39) (Table 2). Primers were synthesized by Qiagen. The TaqMan probes were labeled at the $5^{\prime}$ end with either the fluorescent reporter dye 6-carboxylfluoresceine (FAM) or CAL Fluor Orange 560 (CAL Orange) and labeled at the $3^{\prime}$ end with the black hole quencher dye (BHQ, Biosearch Technologies, Novato, CA) (Table 2). In multiplex PCR experiments, the plant probe was labeled at the $5^{\prime}$ end with TAMRA ( $N, N, N^{\prime}$-tetramethyl-5-carboxyrhodamine) as a reporter dye instead of CAL Orange.

Real-time PCR was performed using an ABI Prism 7700 Sequence Detection System (Perkin Elmer/Applied Biosystems, Foster City, CA) in a total volume of $25 \mu$ l containing $100 \mathrm{pg}$ of DNA template and $1 \times$ TaqMan Universal Master Mix (Perkin Elmer/Applied Biosystems) with an additional $0.5 \mathrm{mM} \mathrm{MgCl}_{2}$. Annealing temperature and magnesium concentration were varied to determine optimum levels for amplification (data not shown). For duplex reactions incorporating both $P$. ramorum and plant primers and probes, an additional $75 \mu \mathrm{M}$ dNTPs was added, while for single reactions using $P$. pseudosyringae primers, an additional $1.5 \mathrm{mM} \mathrm{MgCl} 2$ was added. Cycling conditions were $50^{\circ} \mathrm{C}$ for $2 \mathrm{~min}, 95^{\circ} \mathrm{C}$ for $10 \mathrm{~min}$, and 60 cycles of $95^{\circ} \mathrm{C}$ for $15 \mathrm{~s}$ and $55^{\circ} \mathrm{C}$ for $1 \mathrm{~min}$. The FMPr-1a/FMPr-7 and FMPps-1c/FMPps-2c primer combinations were used at a final primer concentration of $1,000 \mathrm{nM}$ and probe concentration of $400 \mathrm{nM}$, whereas the FMPl2b/FMP13b (plant) primers were used at a final primer concentration of $100 \mathrm{nM}$ and probe concentration of $80 \mathrm{nM}$. For multiplex reactions, we used conditions identical to those for 
duplex reactions except that $50-\mu l$ reaction volumes were used and the plant probe was at a concentration of $400 \mathrm{nM}$. A water blank was included as a negative control in each experiment.

Dilution series experiments. Three repeated experiments with two replications each were performed using spectrophotometrically quantified DNA of $P$. ramorum isolate 288 or $P$. pseudosyringae isolate 471 diluted in sterile distilled water. To determine whether the presence of plant DNA affected the DNA dilution series for $P$. ramorum, experiments were performed using a $P$. ramorum DNA dilution series "spiked" with DNA extracted from uninfected azalea cv. Gloria. Two 6-mm-diameter leaf disks were extracted with the Qbiogene FastDNA Kit in a final volume of $100 \mu \mathrm{l}$ and diluted 1:10. Two microliters of extract was added to a dilution series of $P$. ramorum DNA from isolate 288 ranging from $10 \mathrm{ng}$ down to $100 \mathrm{ag}$, and real-time PCR was performed using only the $P$. ramorum primers and probe as well as a twoway multiplex reaction with the $P$. ramorum primers and probe plus the plant primers and probe (three replications each). In addition, dilution series were made from total DNA extracted from infected rhododendron 'Cunningham's White' inoculated as described above. Individual dilution series were constructed from three separate extractions and two experiments were conducted each using dilution series from all three extractions.
Data analysis. Data acquisition and analysis were performed using the TaqMan data worksheet and software according to the manufacturer's instructions (Applied Biosystems). The cycle threshold $(\mathrm{Ct})$ values for each reaction were calculated automatically by the ABI Prism sequence detection software (version 1.6.3) by determining the PCR cycle number at which the reporter fluorescence exceeded background.

\section{RESULTS}

P. ramorum-specific primers and probe. A high level of $P$. ramorum specificity was observed using the primers FMPr-1a and FMPr-7 and the Pr-FAM probe (Table 2) when tested against 45 other species of Phytophthora (multiple isolates tested for some species) at a concentration of $100 \mathrm{pg}$ of DNA with an annealing temperature of $55^{\circ} \mathrm{C}$ (Table 1). Only $P$. ramorum showed a $\mathrm{Ct}$ value of less than 30 cycles with other species exhibiting no detection after 60 cycles (Fig. 1A; Table 3). Twenty-five diverse isolates of $P$. ramorum were amplified at a concentration of $100 \mathrm{pg}$ of DNA using primers FMPR-1a and FMPr-7 and the Pr-FAM probe, with $\mathrm{Ct}$ values ranging from 22.56 to 28.91 (Table 3). Primers FMPr1a and FMPr-7 and the FAM probe worked successfully at $55^{\circ} \mathrm{C}$, but at $57^{\circ} \mathrm{C}$, amplification became inconsistent (data not shown).

TABLE 1. Isolates of Phytophthora spp. used in this study

\begin{tabular}{|c|c|c|c|c|}
\hline Species & Group $^{a}$ & Isolate number ${ }^{b}$ & Host & Origin \\
\hline Phytophthora arecae & II & $441^{\mathrm{PT}}, \mathrm{IMI} 348342$ & Theobroma cacoa & Indonesia \\
\hline Phytophthora boehmeriae & II & $325^{\mathrm{PT}}, \mathrm{P} 1257^{\mathrm{MC}}$ & Boehmeriae nivia & Papua New Guinea \\
\hline \multirow[t]{2}{*}{ Phytophthora cactorum } & I & $384^{\mathrm{PT}}, \mathrm{NY} 577$ & Fragaria $\times$ ananassa & New York \\
\hline & & $385^{\mathrm{PT}}, \mathrm{NY} 568$ & Malus sylvestris & New York \\
\hline Phytophthora cambivora & VI & $443^{\mathrm{PT}}, 33-4-8$ & Prunus dulcis & California \\
\hline Phytophthora capsici & II & $306^{\mathrm{PT}}, \mathrm{Pc}-\mathrm{m} 1$ & Capsicum annuum & New Jersey \\
\hline \multirow[t]{3}{*}{ Phytophthora cinnamomi } & VI & $\mathrm{Cn}-2^{\mathrm{DJM}}$ (A-2 mating type) & Vaccinium spp. & Florida \\
\hline & & $446^{\mathrm{PT}}, 3210^{\mathrm{GB}}$ & Castenea & California \\
\hline & & $447^{\mathrm{PT}}, 3267^{\mathrm{GB}}$ & Jugulands californica & California \\
\hline Phytophthora citricola & III & $422^{\mathrm{PT}}, \mathrm{CR} 4$ & Cornus & UNK \\
\hline Phytophthora citrophthora & II & $461^{\mathrm{PT}}$ & Rhododendron sp. & Oregon \\
\hline Phytophthora clandestine & I & IMI $287317^{\mathrm{DC}}$ & Trifolium subterranean & Australia \\
\hline Phytophthora colocasiae & IV & $345^{\mathrm{PT}}, 1696^{\mathrm{MC}}$ & Colocasia esculenta & China \\
\hline \multirow{2}{*}{ Phytophthora cryptogea } & VI & $310^{\mathrm{PT}}, 620^{\mathrm{PH}}$ & Pinus lambertiana & Oregon \\
\hline & & $389^{\mathrm{PT}}, \mathrm{NY} 508^{\mathrm{WW}}$ & Prunus avium & California \\
\hline Phytophthora drechsleri & VI & $401^{\mathrm{PT}}$, ATCC 64494 & Solanum tuberosum & Egypt \\
\hline Phytophthora erythroseptica & VI & $374^{\mathrm{PT}}$ & Solanum tuberosum & Maine \\
\hline Phytophthora fragariae fragariae & V & $398^{\mathrm{PT}}, 94-96^{\mathrm{JIM}}$ & Fragaria $\times$ ananassa & Oregon \\
\hline Phytophthora gonapodyides & VI & $392^{\mathrm{PT}}, \mathrm{NY} 414^{\mathrm{WW}}$ & Prunus persica & New York \\
\hline Phytophthora heveae & II & $462^{\mathrm{PT}}, 97-251^{\mathrm{PC}}$ & Rhododendron sp. & Oregon \\
\hline Phytophthora hibernalis & IV & $338^{\mathrm{PT}}$, ATCC $56353,3822^{\mathrm{MC}}$ & Citrus & Australia \\
\hline Phytophthora humicola & V & IMI302303 DC & Soil from citrus & Taiwan \\
\hline Phytophthora idaei & I & IDA3 ${ }^{\mathrm{DC}}$ (Type) & Rubus idaeus & Scotland \\
\hline Phytophthora ilicis & IV & $344^{\mathrm{PT}}, \mathrm{P} 3939^{\mathrm{MC}}$, ATCC 56615 & Ilex aquifolium & Canada \\
\hline Phytophthora inflata & III & IMI $342898^{\mathrm{DC}}$ & Syringa sp. & \\
\hline Phytophthora infestans & IV & $561^{\mathrm{PT}}, \mathrm{P} 30^{\mathrm{JG}}$ & Solanum cardiophyllum & Mexico \\
\hline Phytophthora iranica & I & IMI158964 ${ }^{\mathrm{DC}}$ & Solanum melongera & Iran \\
\hline Phytophthora katsurae & II & IMI360596 DC & Cocos nucifera & Ivory Coast \\
\hline Phytophthora lateralis & $\mathrm{V}$ & $451^{\mathrm{PT}}, 91 / 11 / 1-5^{\mathrm{MG}}$ & Chamaecyparis lawsoniana & Oregon \\
\hline Phytophthora medii & II & IMI129185 & Hevea brasiliensis & India \\
\hline \multirow[t]{2}{*}{ Phytophthora megasperma } & $\mathrm{V}$ & $309^{\mathrm{PT}}, 336^{\mathrm{PH}}$ & Pseudotsuga menziesii & Washington \\
\hline & & $437^{\mathrm{PT}}, \mathrm{IMI} 133317$ & Malus sylvestris & Australia \\
\hline \multirow[t]{2}{*}{ Phytophthora megakarya } & II & $327^{\mathrm{PT}}, \mathrm{P} 132^{\mathrm{CB}}$ & Theobroma cacao & Nigeria \\
\hline & & $328^{\mathrm{PT}}, \mathrm{P} 184^{\mathrm{CB}}$ & Theobroma cacao & Cameroon \\
\hline Phytophthora melonis & VI & IMI325917DC & Cucumis sp. & China \\
\hline Phytophthora mirabilis & IV & $340^{\mathrm{PT}}, \mathrm{ATCC} 64070, \mathrm{P} 3007^{\mathrm{MC}}$ & Mirabilis jalapa & Mexico \\
\hline Phytophthora nemorosa & IV & $482^{\mathrm{PT}}, \mathrm{P}-13^{\mathrm{EH}}$ Type & Lithocarpus densiflorus & California \\
\hline Phytophthora nicotianae & II & $360^{\mathrm{PT}}$ & Solanum tuberosum & Delaware \\
\hline \multirow[t]{3}{*}{ Phytophthora parasitica } & II & $332^{\mathrm{PT}}, \mathrm{P} 1751^{\mathrm{MC}}$ & Nicotiana tabacum & Australia \\
\hline & & $334^{\mathrm{PT}}, \mathrm{P} 3118^{\mathrm{MC}}$ & Lycopersicon esculentum & Australia \\
\hline & & & & (Continued on next page) \\
\hline
\end{tabular}

${ }^{a}$ Waterhouse morphological group (58).

${ }^{\mathrm{b}} \mathrm{CB}=$ Clive Brasier, DC = DNA supplied by David Cooke, $\mathrm{MC}=$ Michael Coffey, KD = Ken Deahl, $\mathrm{PH}=$ Phil Hamm (E. Hansen), DJM = Dave Mitchell, DS = Dave Shaw, PT = Paul Tooley, UCR = University of California at Riverside, SW $=$ Sabine Werres, WW = Wayne Wilcox, DR $=$ Dave Rizzo, CDFA $=$ Cheryl Blomquist, California Department of Food and Agriculture, PC = Plant Clinic identification by Paul Reeser, and JG = J. Galindo.

c Species groupings of Brasier et al. (6). 
Results from real-time PCR based on a DNA dilution series showed that amplification with the $P$. ramorum primers and probe occurred down to $1 \mathrm{fg}$ of template DNA, which had a $\mathrm{Ct}$ value of 42 (Fig. 2A). A standard curve was calculated based on three replicate serial dilutions of DNA extracted from $P$. ramorum isolate 288 and demonstrated the linearity in response of the assay to DNA concentrations (Fig. 2B). Data for the 100-ag quantity was omitted from the standard curve analysis since detection was variable at that low level. Addition of plant DNA in amounts similar to those that would likely be added when assaying field samples slightly reduced the amplification efficiency of $P$. ramorum template amplification (slope of -4.14 compared with -3.68 ); the regression equation for the spiked DNA standard curve was $y=$ $-4.14 \log (x)+21.96$ with an $r^{2}$ value of 0.984 .

$P$. pseudosyringae-specific primers and probe. Primers FMPps1c and FMPps2c and the PpsCALOrange probe (Table 2) specifically detected all six isolates of $P$. pseudosyringae when tested at an annealing temperature of $55^{\circ} \mathrm{C}$ and did not amplify any of the other 45 Phytophthora species (including the closely related $P$. nemorosa) when tested at a concentration of $100 \mathrm{pg}$ of DNA, including 25 isolates of $P$. ramorum (Table 3). Results of a DNA dilution series showed that amplification with the P. pseudosyringae primers and probe occurred down to $10 \mathrm{fg}$ of template DNA, which had an average Ct value (based on six replications) of 39.94 (data not shown). A standard curve was calculated based on three replicate serial dilutions of $P$. pseudosyringae isolate 471 each containing two replications, and the regression demonstrated the linearity in response of the assay to DNA concentrations (Fig. 2C). Data for the 1-fg quantity was omitted from the standard curve analysis since detection was variable at that low level.

Testing primers and probes with plant DNA. Both the $P$. ramorum and $P$. pseudosyringae primers and probes were tested with DNA of the following plant species using an annealing temperature of $55^{\circ} \mathrm{C}$ and no amplification was observed: Rhododendron sp. (cv. Cunningham's White), Glycine max cv. Williams, Solanum demissum, S. cardiophyllum, S. tuberosum cv. Russet Burbank, Lycopersicon esculentum, coast live oak (Q. agrifolia), laurel oak (Q. laurifolia), Kalmia latifolia cv. Olympic Wedding, California bay laurel (U. californica), Pieris japonica, highbush blueberry (Vacinnium corymbosum), tan oak (Lithocarpus densiflorus), Citrus sp., Zauschneria californica, Fragaria $\times$ ananassa, and Juniperus sp.

Sensitivity of detection of real-time PCR assay with infected tissue. We performed a dilution series from rhododendron leaf disks artificially inoculated with $P$. ramorum to determine the approximate limits of pathogen detection in infected tissue (Table 4). Even at dilutions of $10^{-6}$, pathogen detection was observed, albeit with a $\mathrm{Ct}$ value of 55.34. The amount of DNA at each serial dilution of the infected plant extract was estimated using the

TABLE 1. (Continued from preceding page)

\begin{tabular}{|c|c|c|c|c|}
\hline Species & Group $^{\mathrm{a}}$ & Isolate number ${ }^{\mathrm{b}}$ & Host & Origin \\
\hline Phytophthora palmivora & II & $329^{\mathrm{PT}}, \mathrm{P} 131^{\mathrm{CB}}$ & Theobroma cacao & Nigeria \\
\hline \multirow[t]{2}{*}{ Phytophthora phaseoli } & IV & $352^{\mathrm{PT}}, \mathrm{ATCC} 60171, \mathrm{CBS} 556.88$ & Phaseolus lunatus & Unknown \\
\hline & & $373^{\mathrm{PT}}$ & Phaseolus lunatus & Delaware \\
\hline Phytophthora porri & III & CBS782.97 DC & Brassica chinensis & The Netherlands \\
\hline Phytophthora primulae & III & CBS620.97DC & Primula acaulis & Germany \\
\hline \multirow[t]{6}{*}{ Phytophthora pseudosyringae } & IV & $470^{\mathrm{PT}}, \mathrm{P} 193907 \mathrm{~A}^{\mathrm{CDFA}}$ & Manzanita sp. & Royal Oaks, CA \\
\hline & & $471^{\mathrm{PT}}$ & Umbellularia californica & Napa, CA \\
\hline & & $472^{\mathrm{PT}}$ & Umbellularia californica & Calistoga, CA \\
\hline & & $473^{\mathrm{PT}}$ & Umbellularia californica & Yountville, CA \\
\hline & & $484^{\mathrm{PT}}, \mathrm{PSEU} 16^{\mathrm{TJ}}, \mathrm{NFV}-\mathrm{BU} 97-15$ & Fagus sylvatica & Germany \\
\hline & & $485^{\mathrm{PT}}, \mathrm{P} 96^{\mathrm{EH}}$ & Umbellularia californica & Contra Costa Co., CA \\
\hline Phytophthora pseudotsugae & I & $308^{\mathrm{PT}}, \mathrm{H} 270^{\mathrm{PH}}$ & Pseudotsugae menziesii & Oregon \\
\hline Phytophthora quercina & $\mathrm{V}$ & IMI340618 & Quercus robur & Germany \\
\hline \multirow[t]{25}{*}{ Phytophthora ramorum } & IV & Prn- $1^{\mathrm{PT}}, \mathrm{PD} 93 / 844^{\mathrm{sw}}$ & Rhododendron sp. & Netherlands \\
\hline & & Prn-2 ${ }^{\mathrm{PT}}, \mathrm{PD} 94 / 844^{\mathrm{sw}}$ & Rhododendron sp. & Netherlands \\
\hline & & Prn- $3^{\text {PT }}$, PD $98 / 8 / 6743^{\text {sw }}$ & Rhododendron sp. & Netherlands \\
\hline & & Prn-4 $4^{\mathrm{PT}}, \mathrm{PD} 98 / 8 / 6285^{\mathrm{sw}}$ & Rhododendron sp. & Netherlands \\
\hline & & $\operatorname{Prn}-5^{\mathrm{PT}}, \mathrm{PD} 98 / 8 / 2627^{\mathrm{sw}}$ & Rhododendron sp. & Netherlands \\
\hline & & Prn-6 $6^{\text {PT }}$, PD $98 / 8 / 5233^{\text {sw }}$ & Viburnum sp. & Netherlands \\
\hline & & Prg-1 ${ }^{\mathrm{PT}}, \mathrm{BBA} 69082^{\text {sw }}$ & Rhododendron sp. & Germany \\
\hline & & Prg-2 ${ }^{\text {PT }}$, BBA $9 / 95^{\text {sw }}$, CBS101553 (Type) & Rhododendron catawbiense & Germany \\
\hline & & Prg- $3^{\text {PT }}$, BBA $14 / 98-a^{\text {sw }}$ & Rhododendron catawbiense & Germany \\
\hline & & $\operatorname{Prg}-4^{\mathrm{PT}}, \mathrm{BBA} 12 / 98^{\mathrm{sw}}$ & Rhododendron catawbiense & Germany \\
\hline & & $\operatorname{Prg}-5^{\mathrm{PT}}, \mathrm{BBA} 13 / 99-1^{\mathrm{sw}}$ & Rhododendron catawbiense & Germany \\
\hline & & $\operatorname{Prg}-6^{\mathrm{PT}}, \mathrm{BBA} 16 / 99^{\text {sw }}$ & Viburnum bodnantense & Germany \\
\hline & & $\operatorname{Prg}-7^{\mathrm{PT}}, \mathrm{BBA} 9 / 3^{\mathrm{sw}}$ & Water & Germany \\
\hline & & $\operatorname{Prg}-8^{\mathrm{PT}}, \mathrm{BBA} 104^{\mathrm{sw}}$ & Water & Germany \\
\hline & & $288^{\mathrm{MG}}$ & Rhododendron sp. & California \\
\hline & & $73101^{\mathrm{CDFA}}$ & Lithocarpus densiflorus & California \\
\hline & & $044519^{\mathrm{CDFA}}$ & Umbellularia californica & California \\
\hline & & $044522^{\mathrm{CDFA}}$ & Lithocarpus densiflorus & California \\
\hline & & P072648 CDFA & Quercus agrifolia & California \\
\hline & & $201 C^{\mathrm{DR}}$ & Rhododendron sp. & California \\
\hline & & $0-217, \operatorname{Pr}-52^{\mathrm{DR}}$ & Rhododendron sp. & California \\
\hline & & Coen $^{\mathrm{MG}}$ & Rhododendron sp. & California \\
\hline & & $0-13, \operatorname{Pr}-5^{\mathrm{DR}}$ & Lithocarpus densiflorus & California \\
\hline & & $0-16, \operatorname{Pr}-6^{\mathrm{DR}}$ & Quercus agrifolia & California \\
\hline & & $\mathrm{C}^{\mathrm{MG}}$ & Umbellularia californica & California \\
\hline Phytophthora richardiae & VI & ATCC $46538^{\mathrm{DC}}$ & Zantedeschia sp. root & The Netherlands \\
\hline Phytophthora sojae & V & $312^{\mathrm{PT}}$, ATCC 48068 & Glycine max & Wisconsin \\
\hline \multirow[t]{2}{*}{ Phytophthora syringae } & III & $442^{\mathrm{PT}}, \mathrm{P} 1023^{\mathrm{CB}}, \mathrm{IMI} 296829$ & Rubus idaeus & Scotland \\
\hline & & $469^{\mathrm{PT}}$ & Kalmia latifolia & Oregon \\
\hline Phytophthora tentaculata & $\mathrm{I}$ & CBS552.96 ${ }^{\mathrm{DC}}$ & Chrysanthemum leucanth & Germany \\
\hline Phytophthora sp. "O" group & & P246 ${ }^{\mathrm{DC}}, \mathrm{IMI} 389751$ & Salix roots & U.K. \\
\hline P. taxon Raspberry ${ }^{\mathrm{c}}$ & & P896 ${ }^{\mathrm{DC}}, \mathrm{IMI} 389744$ & Soil & Tasmania \\
\hline
\end{tabular}


standard dilution series curve (Fig. 2) with the $10^{-5}$ dilution extrapolated to have $1.7 \mathrm{fg}$ of $P$. ramorum DNA.

Use of two-way multiplex real-time PCR assay with field samples from California. Samples from naturally infected plant hosts in California received from the California Department of Food and Agriculture were evaluated with the $P$. ramorum, $P$. pseudosyringae, and plant primers (Table 5). We performed a two-way multiplex real-time PCR using $P$. ramorum and plant primers and probes. For samples negative for $P$. ramorum, we then performed a second real-time PCR using the $P$. pseudosyringae primers and probe. Results for all 53 samples showed good agreement between the real-time PCR and the results of prior analysis (Table 5). All 14 samples previously determined to be infected with $P$. ramorum were correctly identified with the real-time assay, as were all six of the samples infected with $P$. pseudosyringae. Cross reactivity between these two species or with several other Phytophthora spp. colonizing the tissue was not observed. Importantly, no examples of false positives were obtained. Use of plant primers and probe allowed confirmation that amplifiable DNA was present in all samples and was of high quality and did not contain PCR inhibitors that would prevent amplification and result in false negatives.

Three-way multiplex real-time PCR assay. Experiments were conducted using California bay laurel (U. californica) artificially infected with $P$. ramorum, $P$. pseudosyringae, or both pathogens using their respective primers and probes and plant primers and probes in three-way multiplex reactions. Initial studies were performed to determine optimum concentrations of dNTPs, magnesium, and primers/probes and optimum probe-fluorochrome combinations to prevent competitive interference between the three components in the multiplex reactions (data not shown). Two multiplex experiments were performed at an annealing temperature of $55^{\circ} \mathrm{C}$, with two replications each. Ct values (Table 6) revealed specificity for each pathogen or for plants with each respective primer-probe combination. For the $P$. ramorum primerprobe combination, amplification from samples containing DNA of both pathogens had the same Ct (Table 6) and amplification curve (Fig. 3) to that obtained with $P$. ramorum alone. For the $P$. pseudosyringae primer-probe combination, amplification from samples containing both pathogens not only had a reduced $\mathrm{Ct}$ (Table 6), but the amplification curve was substantially reduced compared with that containing P. pseudosyringae alone (Fig. 3). Use of the plant primer-probe combination in multiplex PCR resulted in similar levels of amplification with individual pathogen samples as well as the combined sample (Fig. 3).

\section{DISCUSSION}

We have described a real-time PCR protocol based on mitochondrial gene regions that offers advantages over conventional PCR procedures and will provide a useful and rapid tool in nation- wide efforts to detect the sudden oak death pathogen, $P$. ramorum. The need for such a test, which combines ease of use along with the specificity of conventional PCR and DNA hybridization (due to the inclusion of a specific TaqMan probe sequence), is especially pressing in light of the recent spread of the pathogen to the Eastern United States via shipments of nursery stock (51). The PCR method we describe can differentiate $P$. ramorum from other Phytophthora spp., some of which can cause similar looking lesions on the same hosts as $P$. ramorum. Using a multiplex format, additional Phytophthora species could be added to the assay as well. The described method uses mitochondrial gene regions rather than nuclear regions for detection, and thus offers the advantage of targeting a different region of the pathogen genome than in other tests. Several other real-time PCR assays for $P$. ramorum have targeted nuclear genes such as the ITS regions $(2,13,23,27,61)$ and $\beta$-tubulin and elicitin genes $(2)$. When used in combination, assays based on different genomic regions are more
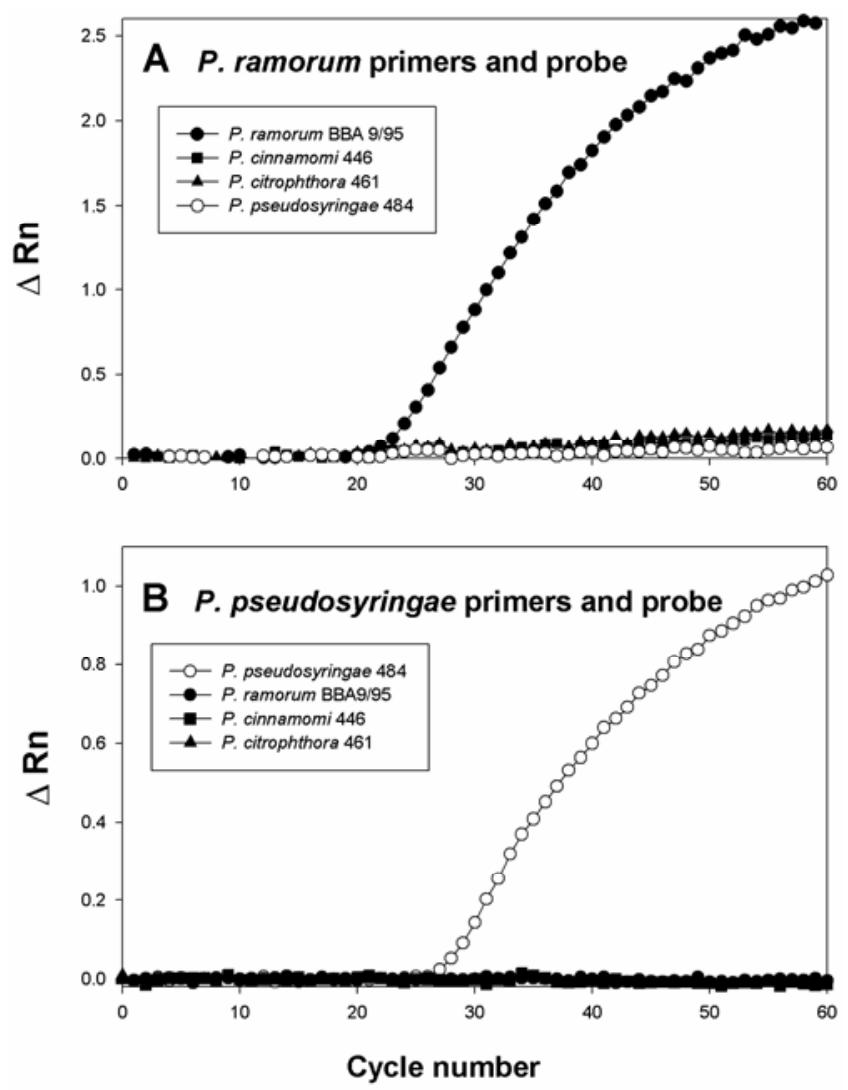

Fig. 1. Real-time amplification profiles for $\mathbf{A}$, Phytophthora ramorum and $\mathbf{B}$, P. pseudosyringae using primers and probes described in Table 2.

TABLE 2. Polymerase chain reaction primer and fluorescent probe sequences used to develop species-specific assays for Phytophthora ramorum and P. pseudosyringae

\begin{tabular}{|c|c|c|c|c|c|}
\hline Target & Primer/probe & Sequence $\left(5^{\prime}\right.$ to $\left.3^{\prime}\right)$ & Length & $T_{m}{ }^{\mathrm{a}}$ & $\% \mathrm{GC}^{\mathrm{b}}$ \\
\hline P. ramorum & FMPr-1a & GTATTTAAAATCATAGGTGTAATTTG & 26 & 50.0 & 23.1 \\
\hline P. ramorum & FMPr-7 & TGGTTTTTTTAATTTATATTATCAATG & 27 & 51.9 & 14.8 \\
\hline P. ramorum & PrFAM probe & 6-FAM d(CAGATATTAAACAAATTATATATAAAATCAAACAA) BHQ-1 ${ }^{c}$ & 35 & 56.2 & 14.3 \\
\hline Plant & FMPl-3b & AGGTTGTATTAAAGTTTCGATCG & 23 & 53.5 & 34.8 \\
\hline Plant & Plant CALOrange probe & CAL Orange d(CTTTTATTATCACTTCCGGTACTGGCAGG) BHQ-1 & 29 & 64.5 & 44.8 \\
\hline P. pseudosyringae & FMPps1c & AGTTTCATTAGAAGATTATTTAC & 23 & 52.1 & 21.7 \\
\hline P. pseudosyringae & FMPps2c & AAAATTGTTTGATTTTATTAAGTATC & 26 & 52.0 & 15.4 \\
\hline
\end{tabular}

${ }^{\text {a }}$ Melting temperature, $T_{m}$, was calculated at $50 \mathrm{nM}$ primer and $50 \mathrm{nM}$ salt using the program Primer Express (Applied Biosystems).

${ }^{\mathrm{b}}$ Percentage of guanulic and cytidylic acid.

${ }^{\mathrm{c}}$ TaqMan probes were labeled at the 5' end with either the fluorescent reporter dye 6-carboxy-fluorescin (FAM) or CAL Fluor Orange (CAL Orange) and labeled at the $3^{\prime}$ end with the black hole quencher dye (BHQ, Biosearch Technologies, Novato, CA). 
powerful and reliable than either test used alone, particularly in cases where one test may result in faint positive reactions and the pathogen cannot be cultured on selective agar medium. The fact that mitochondrial sequences are high copy also aids with the sensitivity of the assay.

However, the high AT/CG ratio and abundance of A and T in mitochondrial DNA offer a challenge to development of molecular detection methods. Methods such as increasing the ratio of dATP and dTTP versus dGTP and dCTP in PCR and/or reducing extension temperatures can enhance amplification of mitochondrial A+T-rich DNAs $(45,52)$. A possible explanation for the reduced sensitivity we observed in multiplex PCR may be the A+Trich nature of primers and probes we designed for use with our mitochondrial target region. Our primers and probes have a G/C base composition that is far below the $50 \%$ composition considered optimum (Table 2). However, it is known that low G/C content can be compensated for by an increase in primer length (10). In spite of such potential difficulties, mitochondrial gene regions have proven useful in identification and detection studies with a number of different fungi $(11,16,38,64)$.

The specificity of our assay was determined by evaluating 45 different Phytophthora species (for some species multiple isolates were examined). In contrast, the specificity of the PCR assay based on the ITS region has been tested with 20 species, some of which ( $P$. lateralis and $P$. cambivora) cross reacted at certain DNA concentrations $(13,23)$. The real-time PCR assay described

TABLE 3. Cycle threshold (Ct) values for 25 isolates of Phytophthora ramorum, P. pseudosyringae, and other Phytophthora species subjected to real-time polymerase chain reaction (PCR) analysis

\begin{tabular}{|c|c|c|}
\hline & \multicolumn{2}{|c|}{ Ct value ${ }^{a}$} \\
\hline & $\begin{array}{c}P \text {. ramorum } \\
\text { primers and probe }\end{array}$ & $\begin{array}{l}\text { P. pseudosyringae } \\
\text { primers and probe }\end{array}$ \\
\hline \multicolumn{3}{|l|}{ P. ramorum } \\
\hline Coen & $28.91 \pm 0.44$ & $>60 \pm 0^{\mathrm{b}}$ \\
\hline $201 C$ & $26.40 \pm 0.13$ & $>60 \pm 0$ \\
\hline $0-13$ & $24.84 \pm 0.46$ & $>60 \pm 0$ \\
\hline $0-16$ & $26.83 \pm 0.56$ & $>60 \pm 0$ \\
\hline $0-217$ & $25.23 \pm 0.11$ & $>60 \pm 0$ \\
\hline 288 & $28.81 \pm 0.05$ & $>60 \pm 0$ \\
\hline $\mathrm{C}$ & $27.40 \pm 0.75$ & $>60 \pm 0$ \\
\hline 73101 & $25.41 \pm 0.55$ & $>60 \pm 0$ \\
\hline 044519 & $25.26 \pm 0.13$ & $>60 \pm 0$ \\
\hline 044522 & $25.28 \pm 0.44$ & $>60 \pm 0$ \\
\hline Prn-1 & $25.66 \pm 0.15$ & $>60 \pm 0$ \\
\hline Prn-2 & $28.45 \pm 0.69$ & $>60 \pm 0$ \\
\hline Prn-3 & $28.87 \pm 0.14$ & $>60 \pm 0$ \\
\hline Prn-4 & $27.25 \pm 0.01$ & $>60 \pm 0$ \\
\hline Prn-5 & $26.73 \pm 1.12$ & $>60 \pm 0$ \\
\hline Prn-6 & $26.68 \pm 0.18$ & $>60 \pm 0$ \\
\hline Prg-1 & $26.88 \pm 0.21$ & $>60 \pm 0$ \\
\hline Prg-2 & $22.56 \pm 0.11$ & $>60 \pm 0$ \\
\hline Prg-3 & $24.86 \pm 0.14$ & $>60 \pm 0$ \\
\hline Prg-4 & $27.07 \pm 0.18$ & $>60 \pm 0$ \\
\hline Prg-5 & $27.49 \pm 0.27$ & $>60 \pm 0$ \\
\hline Prg-6 & $25.02 \pm 0.15$ & $>60 \pm 0$ \\
\hline Prg-7 & $28.53 \pm 0.42$ & $>60 \pm 0$ \\
\hline Prg-8 & $24.37 \pm 0.52$ & $>60 \pm 0$ \\
\hline P72648 & $25.66 \pm 0.76$ & $>60 \pm 0$ \\
\hline \multicolumn{3}{|l|}{ P. pseudosyringae } \\
\hline 470 & $>60 \pm 0$ & $25.41 \pm 0.03$ \\
\hline 471 & $>60 \pm 0$ & $25.01 \pm 0.40$ \\
\hline 472 & $>60 \pm 0$ & $24.52 \pm 0.64$ \\
\hline 473 & $>60 \pm 0$ & $24.11 \pm 0.06$ \\
\hline 484 & $>60 \pm 0$ & $27.74 \pm 0.33$ \\
\hline 485 & $>60 \pm 0$ & $24.93 \pm 0.25$ \\
\hline Other Phytophthora species $^{\mathrm{c}}$ & $>60 \pm 0$ & $>60 \pm 0$ \\
\hline Negative control & $>60 \pm 0$ & $>60 \pm 0$ \\
\hline
\end{tabular}

${ }^{\text {a }}$ Data are mean values of two replicated experiments \pm standard error.

${ }^{\mathrm{b}}$ No fluorescence was detected at 60 cycles of PCR amplification when tested at a concentration of $100 \mathrm{pg}$ of DNA.

c Other species listed in Table 1. here also detected a variety of $P$. ramorum isolates, including those from Europe. U.S. and European populations have been shown to be different for several characters including mating type $(5,59)$ and our assay is able to detect $P$. ramorum from either population. The assay also exhibited a linear response between DNA concentration and detection limit and was sensitive enough to detect $P$. ramorum when present at a concentration of $1 \mathrm{fg}$ of culture extracted DNA. The presence of plant extracts in the amplification mix in the amount equal to what would be used in assays of field samples did not alter the sensitivity of the assay. In fact, DNA extractions from infected leaves from a Rhododendron sp. could be diluted to $10^{-5}$ and the pathogen could still be detected. This marker system was initially developed for conventional nested PCR with the first round amplification done using a genus-specific primer pair followed by nested amplification with the species-specific primer pair (39). While it has not been experimentally verified, conducting conventional PCR with the genusspecific primers followed by the described nested real-time PCR
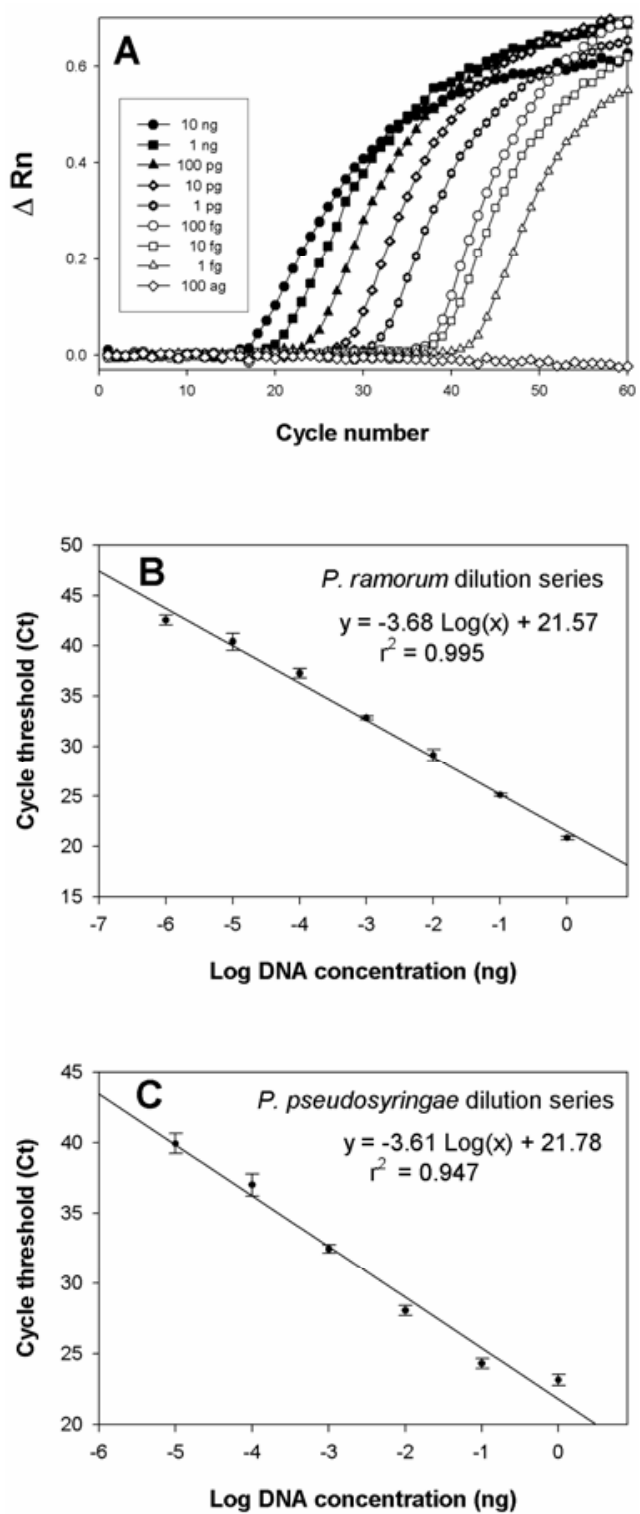

Fig. 2. A, Real-time polymerase chain reaction amplification profile for representative dilution series of DNA extracted from Phytophthora ramorum isolate 288. B, Standard curve of cycle threshold $(\mathrm{Ct})$ values calculated from serial dilutions of DNA from P. ramorum isolate 288 with standard error bars indicated. C, Standard curve of $\mathrm{Ct}$ values calculated from serial dilutions of DNA from $P$. pseudosyringae isolate 471 with standard error bars indicated. 
procedure would be expected to enhance the sensitivity of pathogen detection.

Hayden et al. (23) reported detection of $P$. ramorum down to $12 \mathrm{fg}$ of DNA in an ITS-based PCR assay using SYBR green

TABLE 4. Amount of DNA estimated to be present in dilutions of DNA extracted from Rhododendron sp. (cv. Cunningham's White) leaf disks infected with Phytophthora ramorum

\begin{tabular}{lcc}
\hline $\begin{array}{l}\text { Dilution from } \\
\text { Bio101 kit }\end{array}$ & Ct average $\pm \mathrm{SE}^{\mathrm{b}}$ & $\begin{array}{c}\text { Amount of DNA calculated } \\
\text { from standard curve }\end{array}$ \\
\hline $1: 10$ & $27.75 \pm 0.32$ & $20.9 \mathrm{pg}$ \\
$1: 100$ & $32.06 \pm 0.53$ & $1.4 \mathrm{pg}$ \\
$1: 1000$ & $35.37 \pm 0.62$ & $177 \mathrm{fg}$ \\
$1: 10,000$ & $39.57 \pm 0.33$ & $13 \mathrm{fg}$ \\
$1: 100,000$ & $42.81 \pm 0.58$ & $1.7 \mathrm{fg}$ \\
$1: 1,000,000$ & $55.34 \pm 2.95$ & $\mathrm{ND}^{\mathrm{c}}$ \\
\hline
\end{tabular}

a DNA was extracted from two 6-mm-diameter leaf disks using a Qbiogene Fast DNA Extraction Kit (Qbiogene, Inc., Carlsbad, CA) according to manufacturer's instructions.

${ }^{b}$ Cycle threshold $(\mathrm{Ct})$ values are means of six observations, plus or minus the standard error. Three separate extractions were performed (each using two 6-mm-diameter leaf disks), and two replicate real-time polymerase chain reaction experiments were conducted, each containing sample from all three extractions diluted as indicated $(n=6)$.

${ }^{c} \mathrm{ND}=$ not determined because out of range of the standard curve. detection but several other Phytophthora species cross-reacted in the assay at DNA template concentrations above $0.7 \mathrm{ng}$. SYBR green binds indiscriminately to double-stranded DNA, so false positives caused by detection of primer-dimers and nonspecific amplification are possible (49). Vandemark and Barker (56) reported a detection limit of $1 \mathrm{pg}$ of DNA for $P$. medicaginis using a fluorescent real-time PCR primer-probe set based on a

TABLE 6. Cycle threshold $(\mathrm{Ct})$ values for multiplex experiments with California bay laurel (Umbellularia californica) artificially infected with Phytophthora ramorum, $P$. pseudosyringae, or both pathogens using primers and probes specific for $P$. ramorum, P. pseudosyringae, and plant DNA ${ }^{\mathrm{a}}$

\begin{tabular}{lccc}
\hline Sample & $\begin{array}{c}\text { P. ramorum } \\
\text { primers } \\
\text { and probe }\end{array}$ & $\begin{array}{c}\text { P. pseudosyringae } \\
\text { primers and probe }\end{array}$ & $\begin{array}{c}\text { Plant primers } \\
\text { and probe }\end{array}$ \\
\hline P. ramorum 0-217 & 28.6 & $>60^{\mathrm{b}}$ & 30.6 \\
P. pseudosyringae 470 & $>60$ & 27.5 & 32.3 \\
0-217 plus 470 & 28.5 & 34.2 & 29.1 \\
Negative control & $>60$ & $>60$ & $>60$ \\
MSD $^{c}$ & 0.8 & 5.0 & 1.2
\end{tabular}

${ }^{a}$ Data are means of four observations (two experiments with two replications each).

${ }^{\mathrm{b}}$ No fluorescence was detected at 60 cycles of PCR amplification.

${ }^{\mathrm{c}}$ Minimum significant difference, $K$ ratio $=100$ for Waller-Duncan $K$ ratio $t$ test for $\mathrm{Ct}$ value.

TABLE 5. Real-time polymerase chain reaction (PCR) results for symptomatic plant samples collected from the field in California and processed by the California Department of Food and Agriculture to determine which Phytophthora spp. were present

\begin{tabular}{|c|c|c|c|}
\hline \multirow[b]{2}{*}{ Host species } & \multirow[b]{2}{*}{ Pathogen identification $^{a}$} & \multicolumn{2}{|c|}{ Real-time PCR result $(\mathrm{Ct} \text { value })^{\mathrm{b}}$} \\
\hline & & P. ramorum & P. pseudosyringae \\
\hline Acer macrophyllum (6 samples) & None detected & $>60^{\mathrm{c}}$ & $>60$ \\
\hline Aesculus californica (3 samples) & None detected & $>60$ & $>60$ \\
\hline Arbutus menziesii (2 samples) & None detected & $>60$ & $>60$ \\
\hline Heteromeles arbutifolia (2 samples) & None detected & $>60$ & $>60$ \\
\hline Pseudotsuga menziesii & None detected & $>60$ & $>60$ \\
\hline Rhamnus californica & Phytophthora sp. & $>60$ & $>60$ \\
\hline Rhododendron sp. & P. ramorum & 34 & $>60$ \\
\hline Rhododendron sp. & P. pseudosyringae & $>60$ & 30 \\
\hline Rhododendron sp. & Phytophthora sp. & $>60$ & $>60$ \\
\hline Rhododendron sp. & Phytophthora sp. & $>60$ & $>60$ \\
\hline Rhododendron sp. (2 samples) & P. syringae & $>60$ & $>60$ \\
\hline Rhododendron sp. (2 samples) & None detected & $>60$ & $>60$ \\
\hline Salal sp. & None detected & $>60$ & $>60$ \\
\hline Sambucus sp. & None detected & $>60$ & $>60$ \\
\hline Sequoia sempervirens (2 samples) & None detected & $>60$ & $>60$ \\
\hline Umbellularia californica (8 samples) & P. nemorosa & $>60$ & $>60$ \\
\hline Umbellularia californica & P. pseudosyringae & $>60$ & 30 \\
\hline Umbellularia californica & P. pseudosyringae & $>60$ & 34 \\
\hline Umbellularia californica & P. pseudosyringae & $>60$ & 37 \\
\hline Umbellularia californica & P. pseudosyringae & $>60$ & 32 \\
\hline Umbellularia californica & P. pseudosyringae & $>60$ & 39 \\
\hline Umbellularia californica & $P$. ramorum & 38 & $>60$ \\
\hline Umbellularia californica & P. ramorum & 35 & $>60$ \\
\hline Umbellularia californica & P. ramorum & 41 & $>60$ \\
\hline Umbellularia californica & $P$. ramorum & 41 & $>60$ \\
\hline Umbellularia californica & P. ramorum & 40 & $>60$ \\
\hline Umbellularia californica & P. ramorum & 44 & $>60$ \\
\hline Umbellularia californica & $P$. ramorum & 39 & $>60$ \\
\hline Umbellularia californica & $P$. ramorum & 32 & $>60$ \\
\hline Umbellularia californica & P. ramorum & 35 & $>60$ \\
\hline Umbellularia californica & $P$. ramorum & 38 & $>60$ \\
\hline Umbellularia californica & $P$. ramorum & 40 & $>60$ \\
\hline Umbellularia californica & $P$. ramorum & 37 & $>60$ \\
\hline Umbellularia californica & P. ramorum & 33 & $>60$ \\
\hline Umbellularia californica (4 samples) & None detected & $>60$ & $>60$ \\
\hline
\end{tabular}

a Plant samples from the field were the same as discussed previously (39). They were processed at the California Department of Food and Agriculture by plating on selective medium and confirming species identification based on morphological criteria and/or amplification of DNA extracted from infected tissue with the $P$. ramorum-specific internal transcribed spacer primers. These same samples were evaluated in a prior publication with the Phytophthora genus-specific, P. ramorum, P. nemorosa, and P. pseudosyringae species-specific primer pairs (39).

${ }^{\mathrm{b}}$ Real-time PCR was performed following 1:10 dilution of DNA extract for multiplex amplifications using the plant and the indicated species-specific primers and probe. Results using plant primers and probe were positive for all samples, with cycle threshold (Ct) values ranging from 23 to 34 .

c No fluorescence was detected at 60 cycles of PCR amplification. 
sequence characterized DNA marker. Boehm et al. (4) reported a linear standard curve for detection of $P$. infestans using realtime PCR that ranged from $10^{-6}$ to $1 \mu \mathrm{g}$ of template DNA per $\mathrm{ml}$. This would place the lower limit of detection in the femtogram range similar to the results obtained with our real-time PCR assay.

Multiplex PCR allows for increased sample throughput and lower operating costs since multiple pathogens can be detected within the same plant extract by using different primer-probe combinations in the same reaction. Multiplex real-time PCR assays have been used previously for detecting both host and pathogen in the same reaction $(25,62)$, and conventional (nonreal-time) multiplex PCR was used to detect $P$. lateralis in PortOrford-cedar (61) and multiple fungal pathogens of wheat (17). We evaluated a real-time duplex assay with markers for $P$. ramorum and the plant using infected plant samples from the greenhouse and field samples from California and found a high correlation between the results of the real-time PCR assay and those of culturing and other detection methods. Perhaps due to the presence of PCR inhibitors in the samples with the extraction procedure that was used, a 10-fold dilution of field sample DNA was necessary to obtain consistent amplification. Multiplexing ampli-
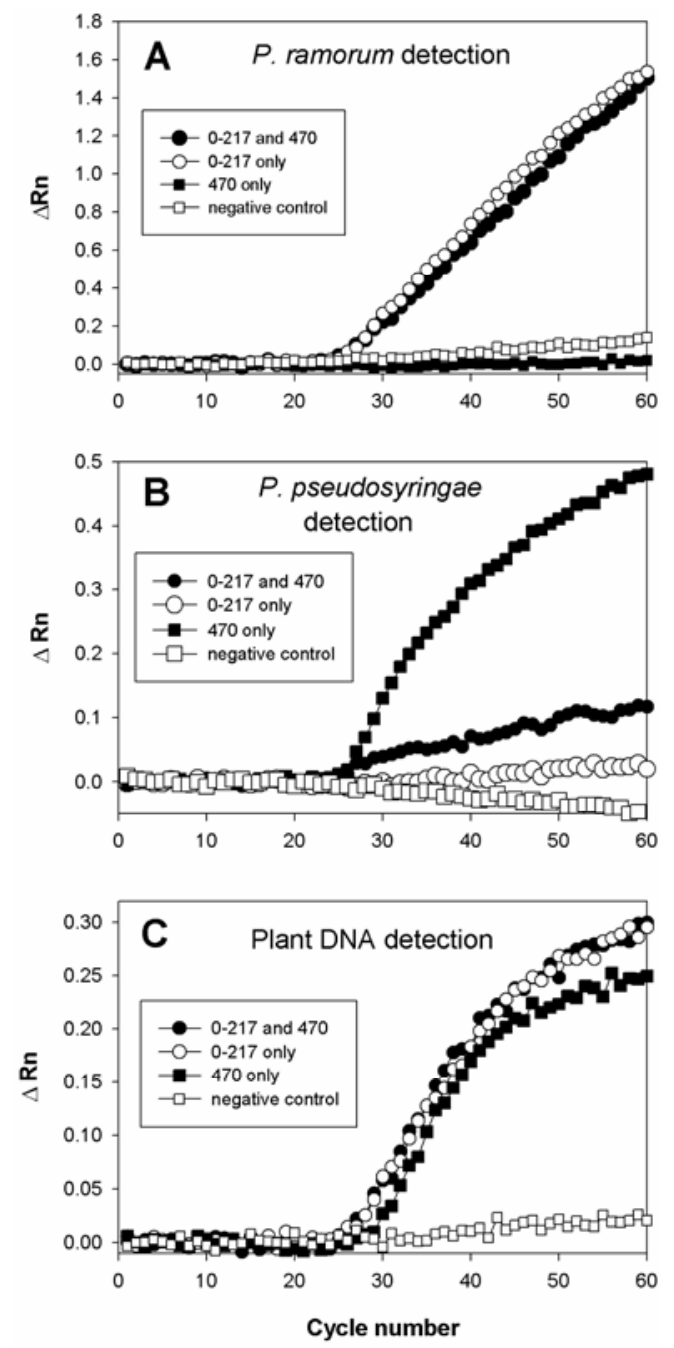

Fig. 3. Amplification profiles from multiplex real-time polymerase chain reaction analysis of leaf samples of California bay laurel (Umbellularia californica) artificially infected with Phytophthora ramorum, P. pseudosyringae, or both pathogens. Multiple experiments were performed; these amplification profiles represent results of a single run. The dye used for the $P$. ramorum probe was A, FAM, that for the $P$. pseudosyringae probe was $\mathbf{B}$, CAL Orange, and that for the plant probe was $\mathbf{C}$, TAMRA. Table 6 provides cycle threshold values associated with multiplex analysis. fication had a limited effect on the sensitivity of detection by the $P$. ramorum markers.

In an effort to simultaneously detect two pathogens causing similar foliar symptoms on some hosts, a three-way multiplex amplification was evaluated using markers for $P$. ramorum, $P$. pseudosyringae, and the plant to serve as a positive control. While multiplexing had no effect on the sensitivity of the $P$. ramorum and plant markers, there was a reduction in the detection sensitivity for the P. pseudosyringae markers (Fig. 3). However, the $\mathrm{Ct}$ values obtained were sufficient to determine whether the target pathogen was present or not in the assay. It is known that PCR efficiencies may be decreased when multiple primer sets are present in a single tube. Also, there exist many variables within PCR assays that can affect the efficiency of multiplexing, including the sequence of the oligonucleotides, concentrations of primers and probes, and concentrations of other PCR components $(10,15)$. One or more of these variables may have been responsible for the observed results.

In the future, we plan to extend the utility of this assay by developing primer-probe combinations for P. nemorosa, a pathogen present in California that is often isolated from material also infected with $P$. ramorum. We also plan to adapt the assay for use in other PCR machines such as the portable SmartCycler (Cepheid, Inc.) platform for more broad use by other laboratories and federal and state regulatory agencies.

\section{ACKNOWLEDGMENTS}

We thank A. Sechler for assistance with development of protocols for real-time PCR; C. Blomquist from the California Department of Agriculture for providing extracts from infected plant materials for these studies; D. Cooke for providing extracted DNA for some Phytophthora spp.; and M. Benson for helpful editorial suggestions. We acknowledge the U.S. Forest Service, Pacific Southwest Research Station, for providing grant support for some of this work from the Sudden Oak Death Research Program.

\section{LITERATURE CITED}

1. Bates, J. A., Taylor, E. J. A., Kenyon, D. M., and Thomas, J. E. 2001. The application of real-time PCR to the identification, detection and quantification of Pyrenophora species in barley seed. Mol. Plant Pathol. 2:4957.

2. Bilodeau, G., Levesque, C. A., de Cock, A. W. A. M., Duchaine, C., Kristjansson, G., and Hamelin, R. C. 2005. Molecular detection of Phytophthora ramorum by real-time PCR using TaqMan, SYBR green and molecular beacons with three genes. Proceedings of the Sudden Oak Death Second Science Symposium: The State of Our Knowledge. M. Haverty, P. Shea, and S. J. Frankel, eds. U.S. Dep. Agric. For. Serv., Gen. Tech. Rep., Pacific Southwest Research Station, Albany, CA. (In press)

3. Bluhm, B. H., Cousin, M. A., and Woloshuk, C. P. 2004. Multiplex realtime PCR detection of fumonisin-producing and trichothecene-producing groups of Fusarium species. J. Food Prot. 67:536-543.

4. Boehm, J., Hahn, A., Schubert, R., Bahnweg, G., Adler, N., Nechwatal, J., Oehlmann, R., and Osswald, W. 1999. Real-time quantitative PCR: DNA determination in isolated spores of the mycorrhizal fungus Glomus mosseae and monitoring of Phytophthora infestans and Phytophthora citricola in their respective host plants. J. Phytopathol. 147:409-416.

5. Brasier, C. 2003. Sudden oak death: Phytophthora ramorum exhibits transatlantic differences. Mycol. Res. 107:258-259.

6. Brasier, C. M., Cooke, D. E., Duncan, J. M., and Hansen, E. M. 2003. Multiple new phenotypic taxa from trees and riparian ecosystems in Phytophthora gonapodyides-P. megasperma ITS clade 6, which tend to be high-temperature tolerant and either inbreeding or sterile. Mycol. Res. 107:277-290.

7. California Department of Food and Agriculture. 2003. CDFA Plant Quarantine Manual. Pages 224.1-224.5 in: Section 301.92 Phytophthora ramorum. CDFA Pest Exclusion Branch, Sacramento, CA.

8. Canadian Food Inspection Agency. 2003. Phytosanitary Requirements to Prevent the Entry of Phytophthora ramorum Associated with Sudden Oak Death into Canada. Canadian Food Inspection Agency Directive D-01-01.

9. Caten, C. C., and Jinks, J. L. 1968. Spontaneous variability of single isolates of Phytophthora infestans. I. Cultural variation. Can. J. Bot. 46:329-348. 
10. Chamberlain, J. S., and Chamberlain, J. R. 1994. Optimization of multiplex PCRs. Pages 38-46 in: The Polymerase Chain Reaction. K. B. Mullis, F. Ferre, and R. A. Gibbs, eds. Birkhauser, Boston, MA.

11. Cohen, S., Allasia, V., Venard, P., Notter, S., Verniere, C., and Panabieres, F. 2003. Intraspecific variation in Phytophthora citrophthora from citrus trees in Eastern Corsica. Eur. J. Plant Pathol. 109:791-805.

12. Cooperative Agriculture Pest Survey program. 2002. Sudden oak death 2002/2003 pilot national survey. 04 March 2003. Center for Environmental and Regulatory Systems (CERIS), Purdue University, West Lafayette, IN. Published online.

13. Davidson, J. M., Werres, S., Garbelotto, M., Hansen, E. M., and Rizzo, D. M. 2003. Sudden oak death and associated diseases caused by Phytophthora ramorum. Online. Plant Health Progress doi:10.1094/PHP-20030707-01-DG.

14. De Merlier, D., Chandelier, A., and Cavelier, M. 2003. First report of Phytophthora ramorum on Viburnum bodnantense in Belgium. Plant Dis. 87:203.

15. Exner, M. M., and Lewinski, M. A. 2002. Sensitivity of multiplex realtime PCR reactions, using the LightCycler and the ABI prism 7700 sequence detection system, is dependent on the concentration of the DNA polymerase. Mol. Cell. Probes 16:351-357.

16. Ferreira, M. A. S. V., Tooley, P. W., Hatziloukas, E., Castro, C., and Schaad, N. W. 1996. Isolation of a species-specific mitochondrial DNA sequence for identification of Tilletia indica, the Karnal bunt of wheat fungus. Appl. Environ. Microbiol. 62:87-93.

17. Fraaije, B. A., Lovell, D. J., Coelho, J. M., Baldwin, S., and Hollomon, D. W. 2001. PCR-based assays to assess wheat varietal resistance to blotch (Septoria tritici and Stagonospora nodorum) and rust (Puccinia striiformis and Puccinia recondita) diseases. Eur. J. Plant Pathol. 107:905-917.

18. Frederick, R. D., Snyder, C. L., Peterson, G. L., and Bonde, M. R. 2002. Polymerase chain reaction assays for the detection and discrimination of the soybean rust pathogens Phakopsora pachyrhizi and P. meibomiae. Phytopathology 92:217-227.

19. Frederick, R. D., Snyder, K. E., Tooley, P. W., Berthier-Schaad, Y., Peterson, G. L., Bonde, M. R., Schaad, N. W., and Knorr, D. A. 2000. Identification and differentiation of Tilletia indica and T. walkerii using the polymerase chain reaction. Phytopathology 90:951-960.

20. Goodwin, S. B., Drenth, A., and Fry, W. E. 1992. Cloning and genetic analysis of two highly polymorphic, moderately repetitive nuclear DNAs from Phytophthora infestans. Curr. Genet. 22:107-115.

21. Guillemette, T., Iacomi-Vasilescu, B., and Simoneau, P. 2004. Conventional and real-time PCR-based assay for detecting pathogenic Alternaria brassicae in cruciferous seed. Plant Dis. 88:490-496.

22. Hansen, E. M., Reeser, P. W., Sutton, W., Winton, L. M., and Osterbauer, N. 2003. First report of A1 mating type of Phytophthora ramorum in North America. Plant Dis. 87:1267.

23. Hayden, K. J., Rizzo, D., Tse, J., and Garbelotto, M. 2004. Detection and quantification of Phytophthora ramorum from California forests using a real-time polymerase chain reaction assay. Phytopathology 94:1075-1083.

24. Henricot, B., and Prior, C. 2004. Phytophthora ramorum, the cause of sudden oak death or ramorum leaf blight and dieback. Mycologist 18:151-156.

25. Hietala, A. M., Eikenes, M., Kvaalen, H., Solheim, H., and Fossdal, C. G. 2003. Multiplex real-time PCR for monitoring Heterobasidion annosum colonization in Norway spruce clones that differ in disease resistance. Appl. Environ. Microbiol. 69:4413-4420.

26. Holland, P. M., Abramson, R. D., Watson, R., and Gelfand, D. H. 1991. Detection of specific polymerase chain reaction product by utilizing the $5^{\prime}$ to $3^{\prime}$ exonuclease activity of Thermus aquaticus DNA polymerase. Proc. Natl. Acad. Sci. USA 88:7276-7280.

27. Hughes, K., Griffin, R., Tomlinson, J., Boonham, N., Barton, V., Giltrap, P., Hobden, E., Walker, L., Humphries, G., Barnes, A., Beales, P., Inman, A., and Lane, C. 2005. Comparative evaluation of real-time PCR (TaqMan) with isolation for diagnosis of Phytophthora ramorum. Poster no. 43 in: Proceedings of the Sudden Oak Death Second Science Symposium: The State of Our Knowledge. M. Haverty, P. Shea, and S. J. Frankel, eds. U.S. Dep. Agric. For. Serv., Gen. Tech. Rep., Pacific Southwest Research Station, Albany, CA. (In press)

28. Inman, A. J., Townend, V. C., Barnes, A. V., Lane, C. R., Hughes, K. J. D., Griffin, R. L., and Eales, S. J. 2003. First report of Ramorum dieback (Phytophthora ramorum) on Pieris in England. New Dis. Rep. 7. Published online by the British Society for Plant Pathology.

29. Ippolito, A., Schena, L., Nigro, F., Ligorio, V.-S., and Yaseen, T. 2004. Real-time detection of Phytophthora nicotianae and P. citrophthora in citrus roots and soil. Eur. J. Plant Pathol. 110:833-843.

30. Isayenkov, S., Fester, T., and Hause, B. 2004. Rapid determination of fungal colonization and arbuscule formation in roots of Medicago truncatula using real-time (RT) PCR. J. Plant Physiol. 161:1379-1383.

31. Jones, J. 2004. APHIS List of plants regulated and associated with Phytophthora ramorum. Published online by USDA-APHIS.
32. Kong, P., Hong, C. X., Tooley, P. W., Ivors, K., Garbelotto, M., and Richardson, P. A. 2004. Rapid identification of Phytophthora ramorum using PCR-SSCP analysis of ribosomal DNA ITS-1. Lett. Appl. Microbiol. 38:433-439.

33. Kroon, L. P. N. M., Verstappen, E. C. P., Kox, L. F. F., Flier, W. G., and Bonants, P. J. M. 2004. A rapid diagnostic test to distinguish between American and European populations of Phytophthora ramorum. Phytopathology 94:613-620.

34. Mackay, I. M., Arden, K. E., and Nitsche, A. 2002. Real-time PCR in virology. Nucleic Acids Res. 30:1292-1305.

35. Malorny, B., Paccassoni, E., Fach, P., Bunge, C., Martin, A., and Helmuth, R. 2004. Diagnostic real-time PCR for detection of Salmonella in food. Appl. Environ. Microbiol. 70:7046-7052.

36. Martin, F. N., and Tooley, P. W. 2003. Phylogenetic relationships among Phytophthora species inferred from sequence analysis of mitochondrially encoded cytochrome oxidase I and II genes. Mycologia 95:269-284.

37. Martin, F. N., and Tooley, P. W. 2003. Phylogenetic relationships of Phytophthora ramorum, $P$. nemorosa, and $P$. pseudosyringae, three species recovered from areas in California with sudden oak death. Mycol. Res. 12:1379-1391.

38. Martin, F. N., and Tooley, P. W. 2004. Identification of Phytophthora isolates to species level using restriction fragment length polymorphism analysis of a polymerase chain reaction-amplified region of mitochondrial DNA. Phytopathology 94:983-991.

39. Martin, F. N., Tooley, P. W., and Blomquist, C. 2004. Molecular detection of Phytophthora ramorum, the causal agent of sudden oak death in California, and two additional species commonly recovered from diseased plant material. Phytopathology 94:621-631.

40. Moralejo, E., and Werres, S. 2002. First report of Phytophthora ramorum on Rhododendron sp. in Spain. Plant Dis. 86:1052.

41. Parke, J. L., Linderman, R. G., Osterbauer, N. K., and Griesbach, J. A. 2004. Detection of Phytophthora ramorum blight in Oregon nurseries and completion of Koch's postulates on Pieris, Rhododendron, Viburnum, and Camellia. Plant Dis. 88:87.

42. Phytophthora ramorum. Code of Federal Regulations. 2003 ed. Title 7, Pt. 301.92. Pages 142-148. U.S. Gov. Printing Office, Washington, DC.

43. Rinttila, T., Kassinen, A., Malinen, E., Krogius, L., and Palva, A. 2004. Development of an extensive set of 16S rDNA-targeted primers for quantification of pathogenic and indigenous bacteria in faecal samples by real-time PCR. J. Appl. Microbiol. 97:1166-1177.

44. Rizzo, D. M., Garbelotto, M., Davidson, J. M., Slaughter, G. W., and Koike, S. T. 2002. Phytophthora ramorum as the cause of extensive mortality of Quercus spp. and Lithocarpus densiflorus in California. Plant Dis. 86:205-214

45. Rondan-Duenas, J. C., Panzetta-Dutari, G. M., and Gardenal, C.-N. 1999. Specific requirements for PCR amplification of long mitochondrial A+Trich DNA. Biotechniques 27:258-260.

46. Schaad, N. W., and Frederick, R. D. 2002. Real-time PCR and its application for rapid plant disease diagnostics. Can. J. Plant Pathol. 24:250-258.

47. Schena, L., Nigro, F., and Ippolito, A. 2004. Real time PCR detection and quantification of soilborne fungal pathogens: The case of Rosellinia necatrix, Phytophthora nicotianae, P. citrophthora, and Verticillium dahliae. Phytopathol. Mediterr. 43:273-280.

48. Schena, L., Nigro, F., Ippolito, A., and Gallitelli, D. 2004. Real-time quantitative PCR: A new technology to detect and study phytopathogenic and antagonistic fungi. Eur. J. Plant Pathol. 110:893-908.

49. Schnerr, H., Niessen, L., and Vogel, R. F. 2001. Real time detection of the Tri5 gene in Fusarium species by LightCycler PCR using SYBR Green I for continuous fluorescence monitoring. Int. J. Food Microbiol. 71:53-61.

50. Smith, M. S., Yang, R. K., Knapp, C. W., Niu, Y. F., Peak, N., Hanfelt, M. M., Galland, J. C., and Graham, D. W. 2004. Quantification of tetracycline resistance genes in feedlot lagoons by real-time PCR. Appl. Environ. Microbiol. 70:7372-7377.

51. Stokstad, E. 2004. Nurseries may have shipped sudden oak death pathogen nationwide. Science 303:1959.

52. Su, X.-Z., Wu, Y., Sifri, C. D., and Wellems, T. E. 1996. Reduced extension temperatures required for PCR amplification of extremely A+T-rich DNA. Nucleic Acids Res. 24:1574-1575.

53. Tooley, P. W., Kyde, K. L., and Englander, L. 2004. Susceptibility of selected ericaceous ornamental host species to Phytophthora ramorum. Plant Dis. 88:993-999.

54. USDA Animal Plant Health Inspection Service. 2004. Sudden oak death: Phytophthora ramorum. Pest Detection and Management Programs. Published online by USDA Animal Plant Health Inspection Service.

55. van de Graaf, P., Lees, A. K., Cullen, D. W., and Duncan, J. M. 2003. Detection and quantification of Spongospora subterranea in soil, water and plant tissue samples using real-time PCR. Eur. J. Plant Pathol. 109:589-597.

56. Vandemark, G. J., and Barker, B. M. 2003. Quantifying Phytophthora medicaginis in susceptible and resistant alfalfa with a real-time fluorescent PCR assay. J. Phytopathol. 151:577-583. 
57. Wang, P. H., Boo, L. M., Lin, Y. S., and Yeh, Y. 2002. Specific detection of Pythium aphanidermatum from hydroponic nutrient solution by booster PCR with DNA primers developed from mitochondrial DNA. Phytoparasitica 30:473-485.

58. Waterhouse, G. M. 1963. Key to the species of Phytophthora de Bary. Mycological Paper 92. Commonwealth Mycological Institute, Kew, UK.

59. Werres, S., and De Merlier, D. 2003. First detection of Phytophthora ramorum mating type A2 in Europe. Plant Dis. 87:1266.

60. Werres, S., Marwitz, R., Man In't Veld, W. A., DeCock, A. W. A. M., Bonants, P. J. M., De Weerdt, M., Themann, K., Ilieva, E., and Baayen, R. P. 2001. Phytophthora ramorum sp. nov., a new pathogen on Rhododendron and Viburnum. Mycol. Res. 105:1155-1165.
61. Winton, L. M., and Hansen, E. M. 2001. Molecular diagnosis of Phytophthora lateralis in trees, water, and foliage baits using multiplex polymerase chain reaction. For. Pathol. 31:275-283.

62. Winton, L. M., Stone, J. K., Watrud, L. S., and Hansen, E. M. 2002. Simultaneous one-tube quantification of host and pathogen DNA with real-time polymerase chain reaction. Phytopathology 92:112-116.

63. Xu, D.-Y., Huang, H., and Wang, C.-P. 1982. Polyacrylamide gel disc electrophoresis of proteins from species of Phytophthora. Acta Mycol. Sin. 1:40-47.

64. Zeng, Q.-Y., Rasmuson-Lestander, A., and Wang, X.-R. 2004. Extensive set of mitochondrial LSR rDNA-based oligonucleotide probes for the detection of common airborne fungi. FEMS Microbiol. Lett. 237:79-87. 